ALMEIDA, Bruno Rotta; SALLET, Bruna Hoisler. Realidades prisionais e vulnerabilização étnica: aspectos sobre a questão indígena no sistema penitenciário brasileiro. Revista Eletrônica Direito e Política, Programa de Pós-Graduação Stricto Sensu em Ciência Jurídica da UNIVALI, Itajaí, v.13, n.3, $3^{\circ}$ quadrimestre de 2018. Disponível em: www.univali.br/direitoepolitica - ISSN 1980-7791

\title{
O IMPACTO DA REFORMA TRABALHISTA NAS NEGOCIAÇÕES COLETIVAS DE TRABALHO
}

\author{
THE IMPACT OF BRAZILIAN LABOR REFORM BILL IN THE COLLECTIVE \\ BARGAINING
}

\section{Rafael Grassi Pinto Ferreira ${ }^{1}$}

SUMÁRIO: Introdução; 1 A segurança jurídica como motivação da reforma; 20 papel dos sindicatos; 3 A nova negociação coletiva; Considerações finais; Referências das fontes citadas.

\section{RESUMO}

Em 11 de novembro de 2017 entrou em vigor no Brasil a Lei 13.467/2017 que alterou a Consolidação das Leis do Trabalho e outras normas trabalhistas e previdenciárias. A proposta de reforma trabalhista partiu do Poder Executivo e, ao chegar ao Poder Legislativo, gerou intensos debates entre grupos ideologicamente antagônicos que, ainda hoje, estão em curso. O objetivo deste trabalho é identificar, de forma indutiva, a motivação das alterações promovidas pela Lei 13.467/2017 nas negociações coletivas de trabalho e discutir o papel dos sindicatos e empresas no novo cenário jurídico brasileiro. Ao final, pretende-se demonstrar que uma legislação que ofereça maior segurança jurídica e respeite a autonomia da vontade coletiva tem o potencial de valorizar as negociações sindicais de trabalho como um instrumento jurídico de solução de conflitos e de construção vantagens que interesse de trabalhadores e empresas, incrementando as relações capital-trabalho no Brasil.

Palavras-chave: justiça do trabalho; negociação coletiva; reforma trabalhista; sindicato; segurança jurídica.

\section{ABSTRACT}

On November $1^{\text {th }}, 2017$, came into force in Brazil the law 13.467, that altered the Labour Law Code and other labour and social security rules. The labour law reform was proposed by the Executive Power and when submitted to the Brazilian National Congress created intense debates between ideologically antagonistic groups and, even today, raises controversial interpretations. One of the most controversial

\footnotetext{
${ }^{1}$ Rafael Grassi Pinto Ferreira é advogado, bacharel em direito pela Universidade Federal de Minas Gerais - UFMG, especialista em Direito Empresarial pela PUC/MG, especialista em Direito do Trabalho pela Universidade Gama Filho/RJ, MBA em Gestão de Recursos Humanos pela Fundação Getúlio Vargas/RJ, MBA em Gestão e Judiciário pela Fundação Getúlio Vargas/RJ e mestrando em Direito das Relações Econômicas e Sociais pela Faculdade de Direito Milton Campos-MG. E-mail: rafaelgrassi@globo.com.
} 
ALMEIDA, Bruno Rotta; SALLET, Bruna Hoisler. Realidades prisionais e vulnerabilização étnica: aspectos sobre a questão indígena no sistema penitenciário brasileiro. Revista Eletrônica Direito e Política, Programa de Pós-Graduação Stricto Sensu em Ciência Jurídica da UNIVALI, Itajaí, v.13, n.3, $3^{\circ}$ quadrimestre de 2018. Disponível em: www.univali.br/direitoepolitica - ISSN 1980-7791

points concerns the prevalence of the negotiated over the legislated, and consequently, over the limits and possibilities of collective bargaining. The objective of this study is to identify the reason of the amendments brought by Law $13.467 / 2017$ in the labor collective bargaining and to discuss the role of trade unions and companies in a new legal scenario. At the end, this paper intends to demonstrate that legislation that provides greater legal certainty and respect the collective autonomy has the potential to enhance the collective bargaining as a legal instrument of conflict resolution and construction advantages for workers and companies, increasing the capital-labor relations in Brazil.

Keywords: labour reform; collective bargaining; trade union; labour court, legal security.

\section{INTRODUÇÃO}

Em 11 de novembro de 2017, entrou em vigor a Lei $13.467^{2}$ que atualizou a legislação trabalhista. O sentimento que domina o cenário jurídico brasileiro e reverbera para os atores sociais que habitam os polos da relação jurídica é o de expectativa.

As empresas têm expectativa de que, agora com a legislação modernizada, podem colher os frutos de um ambiente jurídico mais favorável à economia, à geração de empregos, ao incremento da produção e geração de receitas. Os empregados e os sindicatos profissionais, a despeito da flexibilização e da diminuição de algumas garantias, têm expectativa de manter os direitos trabalhistas já conquistados, bem como, esperam que ainda haja espaço para novas e necessárias conquistas, através da resistência da classe trabalhadora e das instituições que lhe dão suporte.

Poucas relações jurídicas são tão intensas quanto a relação capital-trabalho, na qual os trabalhadores, em busca de sustento, entregam ao patrão as suas forças físicas e mentais por oito horas diárias e, por outro lado, o patrão entrega ao empregado o seu patrimônio em busca de produção e crescimento.

2 BRASIL. Lei no 13.467, de 13 de julho de 2017. Altera a Consolidação das Leis do Trabalho (CLT), aprovada pelo Decreto-Lei no 5.452, de 10 de maio de 1943, e as Leis nos 6.019 , de 3 de janeiro de 1974, 8.036, de 11 de maio de 1990, e 8.212, de 24 de julho de 1991. Disponível em: http://www.planalto.gov.br/ccivil_03/_Ato2015-2018/2017/Lei/L13467.htm. Acesso em 02 set. 2017. 
ALMEIDA, Bruno Rotta; SALLET, Bruna Hoisler. Realidades prisionais e vulnerabilização étnica: aspectos sobre a questão indígena no sistema penitenciário brasileiro. Revista Eletrônica Direito e Política, Programa de Pós-Graduação Stricto Sensu em Ciência Jurídica da UNIVALI, Itajaí, v.13, n.3, $3^{\circ}$ quadrimestre de 2018. Disponível em: www.univali.br/direitoepolitica - ISSN 1980-7791

Utopia imaginar que essa relação será um dia completamente livre de conflitos. Mas é necessário buscar mecanismos de diminuição das tensões inerentes à prestação laboral.

O empregado tem que se sentir acolhido por uma legislação que lhe confira proteção suficiente contra os abusos patronais e o empresário tem que se sentir acolhido por uma base jurídica que lhe proporcione segurança para não arriscar seu patrimônio em aventuras descontroladas.

Segurança é, portanto, uma palavra mágica para empregados e empreendedores. E nesse contexto os sindicatos tem um papel fundamental, que é o de lutar, através de negociações coletivas, por incrementos salariais e melhorias nas condições de trabalho que necessariamente resultarão também na melhoria da vida dos trabalhadores.

Por isso, cabe perquirir se é necessário rever a forma de atuação de empresas e trabalhadores em negociações coletivas, diante da legislação atual, reformada pela Lei $13.467 / 2017$, e se é possível extrair das novas regras relativas às negociações coletivas de trabalho, a segurança jurídica pretendida por empregados e empregadores, com reflexos econômicos e sociais.

De forma indutiva, analisaremos normas, dados e situações particularmente relacionados com a negociação coletiva e com a relação capital-trabalho para deles obter um diagnóstico adequado para as negociações coletivas. Utilizaremos como marco teórico inicial a doutrina clássica de Arnaldo Süssekind, como um dos idealizadores da norma reformada, especialmente no que tange ao regramento das negociações coletivas, associada à argumentação jurídica e sociológica dos analistas da norma reformadora. 
ALMEIDA, Bruno Rotta; SALLET, Bruna Hoisler. Realidades prisionais e vulnerabilização étnica: aspectos sobre a questão indígena no sistema penitenciário brasileiro. Revista Eletrônica Direito e Política, Programa de Pós-Graduação Stricto Sensu em Ciência Jurídica da UNIVALI, Itajaí, v.13, n.3, $3^{\circ}$ quadrimestre de 2018. Disponível em: www.univali.br/direitoepolitica - ISSN 1980-7791

\section{A SEGURANÇA JURÍDICA COMO MOTIVAÇÃO DA REFORMA}

A primeira discussão que deve ser travada é sobre a necessidade ou desnecessidade da reforma trabalhista implantada no Brasil, o que nos leva a indagar se a Consolidação das Leis do Trabalho (CLT) estaria atualizada e apta a regulamentar as relações de trabalho subordinado. De acordo com o professor da Universidade de São Paulo (USP), Jorge Luiz Souto Maior, não seria correto dizer que a CLT estaria desatualizada tendo em vista que, dentre os seus 922 artigos, somente 625 dizem respeito aos direitos materiais e os demais regulam o processo do trabalho ${ }^{3}$. Diz ainda, o mencionado professor, que dentre os 625 artigos que tratam dos direitos trabalhistas materiais apenas 255 artigos não foram alterados ou revogados por leis posteriores, conservando a redação original de 1943.

Adotando essa ótica, é forçoso concordar que a CLT é um conjunto dinâmico de normas e que não seria correta a pecha de que ela está estagnada na década de 1940.

Por outro lado, ao analisar detidamente a data de publicação de cada uma das centenas de leis que alteraram a CLT ao longo dos anos, é possível perceber que mais de $80 \%$ (oitenta por cento) das alterações ocorreram nas décadas de 1940 a 1970 e menos de 20\% (vinte por cento) das alterações ocorreram a partir de 1980 (Figura 1):

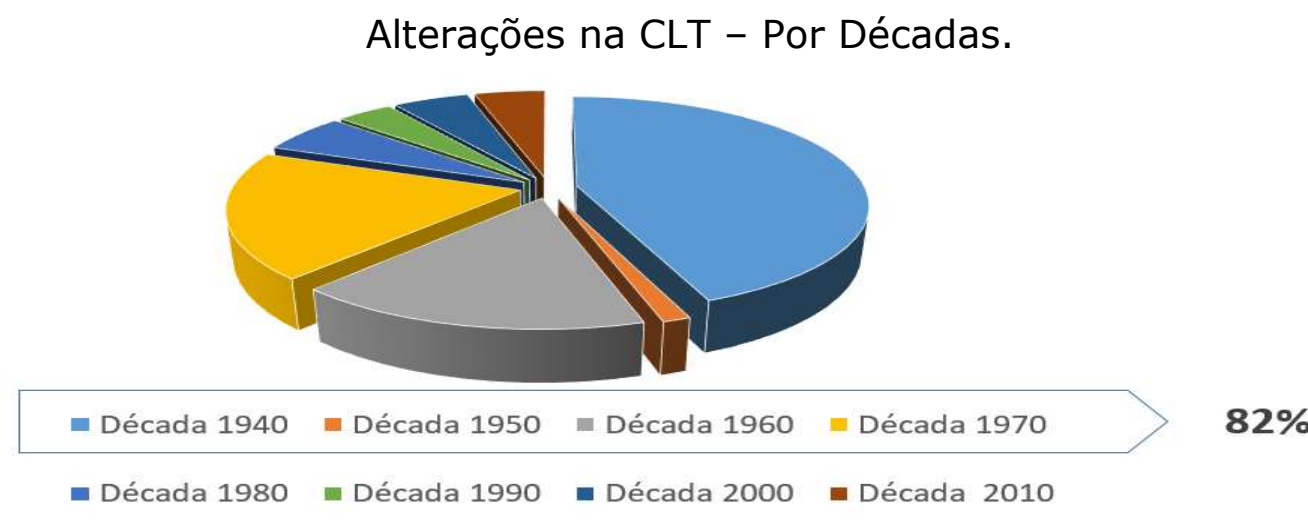

Figura 1.

Fonte: site planalto.gov

3 MAIOR, José Luiz Souto. "A CLT é velha". Disponível em: http://www.jorgesoutomaior.com/blog/i-a-clt-e-velha. Acesso em 01.09.2017 
ALMEIDA, Bruno Rotta; SALLET, Bruna Hoisler. Realidades prisionais e vulnerabilização étnica: aspectos sobre a questão indígena no sistema penitenciário brasileiro. Revista Eletrônica Direito e Política, Programa de Pós-Graduação Stricto Sensu em Ciência Jurídica da UNIVALI, Itajaí, v.13, n.3, $3^{\circ}$ quadrimestre de 2018. Disponível em: www.univali.br/direitoepolitica - ISSN 1980-7791

Esses dados revelam que ocorreu um movimento inversamente proporcional, ou seja, as relações capital-trabalho tornaram-se mais dinâmicas após a década de 1970 e, contraditoriamente, o processo legislativo para atualização da Consolidação das Leis do Trabalho tornou-se menos dinâmico a partir do final da mesma década de 1970.

A grande maioria das alterações ocorreu durante os governos militares, em épocas em que as empresas e trabalhadores ainda não utilizavam os meios de produção e tecnologias atuais, sequer contavam com aparelho fac símile, muito menos com computadores, telefones celulares, internet, whatsapp, etc, sendo possível afirmar que, a despeito das inúmeras alterações, a CLT tornou-se paulatinamente desatualizada e a reforma aprovada pela Lei 13.467/2017, que entrou em vigor me 11 de dezembro de 2017, pretendeu realizar um necessário tratamento do estoque de demandas represadas.

Um primeiro sintoma desta carência de atualização é a quantidade de súmulas e orientações jurisprudenciais editadas pela Justiça do Trabalho. A partir de 1969, o Tribunal Superior do Trabalho editou 1.292 súmulas, orientações jurisprudenciais do Tribunal Pleno, orientações jurisprudenciais (OJ) das Subseções de Dissídios Individuais (SBDI) e precedentes normativos e orientações jurisprudenciais da Seção de Dissídios Coletivos (SDC), conforme se vê no quadro abaixo (Figura 2):

Jurisprudência do Tribunal Superior do Trabalho - TST

\begin{tabular}{|l|r|}
\hline Norma & Quantidade \\
\hline Súmulas & 463 \\
\hline OJ -SBDI-I & 421 \\
\hline OJ SBDI-II & 158 \\
\hline OJ SBDI-I-TRANSITÓRIA & 79 \\
\hline OJ SDC & 38 \\
\hline PN - SDC & 120 \\
\hline TOTAL & 1292 \\
\hline
\end{tabular}

Figura 2

Fonte: Tribunal Superior do Trabalho

A quantidade de intervenções do Tribunal Superior do Trabalho na legislação trabalhista (1292) é quarenta por cento superior ao número de artigos da Consolidação das Leis do Trabalho (922). 
ALMEIDA, Bruno Rotta; SALLET, Bruna Hoisler. Realidades prisionais e vulnerabilização étnica: aspectos sobre a questão indígena no sistema penitenciário brasileiro. Revista Eletrônica Direito e Política, Programa de Pós-Graduação Stricto Sensu em Ciência Jurídica da UNIVALI, Itajaí, v.13, n.3, 30 quadrimestre de 2018. Disponível em: www.univali.br/direitoepolitica - ISSN 1980-7791

A intervenção do Tribunal Superior do Trabalho na legislação trabalhista, como poder legiferante, fica ainda mais evidente quando é comparada com os outros tribunais superiores. Nem mesmo o Superior Tribunal de Justiça (STJ) ou o Supremo Tribunal Federal (STF) que possuem competência para julgar diversas matérias (Cível, Penal, Administrativa, Tributária, Previdenciária, Trabalhista, etc.) e que são mais antigos, editaram quantitativo semelhante de súmulas, incluindo as súmulas vinculantes, conforme se vê no quadro abaixo (Figura 3), que inclui, além da quantidade de súmulas dos tribunais superiores já referidos, os quantitativos do Tribunal Superior Eleitoral (TSE) e do Superior Tribunal Militar (STM):

Comparativo dos Tribunais Superiores - Quantidade de Súmulas

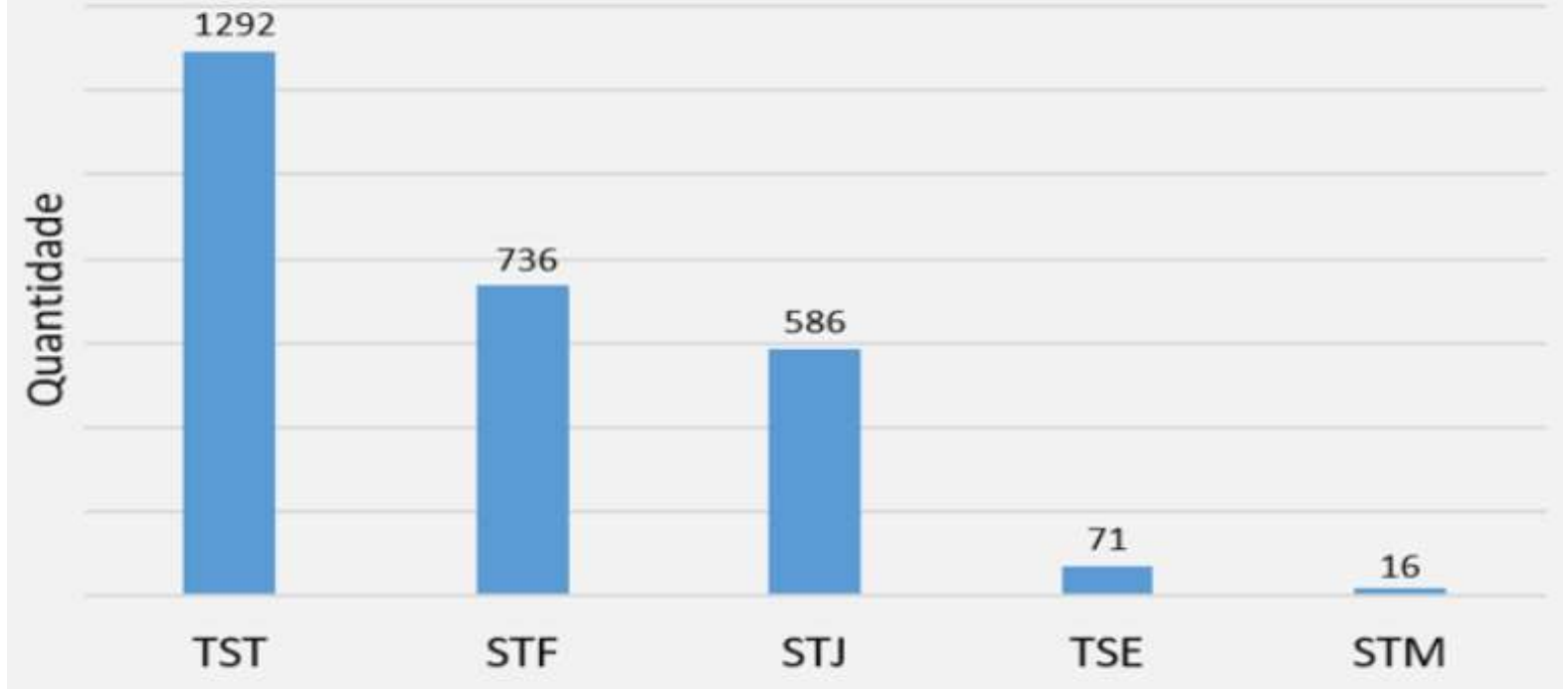

Figura 3.

Fontes: sites dos Tribunais Superiores.

Como é sabido, as súmulas e precedentes do Tribunal Superior do Trabalho, em sua grande maioria, estabelecem interpretações e ampliações dos direitos dos trabalhadores no exercício de um dos princípios fundamentais do direito do trabalho que é o princípio da proteção do trabalhador, com o objetivo de diminuir a grande desigualdade entre as partes - empregados e empregadores - na relação jurídica entre elas estabelecida. 
ALMEIDA, Bruno Rotta; SALLET, Bruna Hoisler. Realidades prisionais e vulnerabilização étnica: aspectos sobre a questão indígena no sistema penitenciário brasileiro. Revista Eletrônica Direito e Política, Programa de Pós-Graduação Stricto Sensu em Ciência Jurídica da UNIVALI, Itajaí, v.13, n.3, $3^{\circ}$ quadrimestre de 2018. Disponível em: www.univali.br/direitoepolitica - ISSN 1980-7791

Contudo, é preciso recorrer ao jurista Américo Plá Rodrigues para resgatar o real alcance do princípio da proteção do empregado e demonstrar o quanto dele o Tribunal Superior do Trabalho se afastou:

Não se trata de corrigir a norma, nem sequer de integrá-la: somente cabe utilizar esta regra quando existe uma norma e unicamente para determinar-lhe o verdadeiro sentido, entre os vários possíveis. De sorte que, quando uma norma não existe, não é possível recorrer a este procedimento para substituir o legislador e muito menos é possível usar esta regra para afastar-se do significado claro da norma. ${ }^{4}$

Em harmonia com os ensinamentos de RODRIGUES é relevante conhecer a reflexão feita pelo Presidente do Tribunal Superior do Trabalho, Ministro Ives Gandra Martins Filho sobre a utilização desvirtuada do princípio da proteção do trabalhador:

A maior tentação a que somos submetidos como juízes do trabalho, é a de acharmos que sabemos melhor o que é bom para os trabalhadores e empregadores do que eles mesmos. Tal tentação, fundada, devemos reconhecer, na vaidade em relação às próprias ideias e no orgulho de achar que nossa visão é melhor que a alheia, tem levado a supervalorizar o princípio da proteção e a desprezar o princípio da subsidiariedade, em sistemática intervenção judicial nas relações laborais $[\ldots]^{5}$

Outro sintoma da carência de mudanças na legislação trabalhista é a tumultuada tramitação do PL 6787/2016 que deu origem à Lei no. 13.467/2017. O projeto inicial do Poder Executivo se limitava a alterar sete artigos e revogar outros seis artigos da Consolidação das Leis do Trabalho. Contudo, ao chegar na Câmara dos Deputados, o projeto original recebeu 1.340 ementas (incluindo as emendas aos doze substitutivos) e, ao final, resultou na alteração ou revogação de 106 artigos da legislação trabalhista consolidada.

\footnotetext{
4 RODRIGUES, Américo Plá. Princípios do Direito do Trabalho. São Paulo: Editora LTr, 1993, p. 45

5 MARTINS FILHO, Ives Gandra. Reflexões com Vistas à Modernização da Legislação Trabalhista por Ocasião dos 75 anos da Justiça do Trabalho no Brasil. $1^{\circ}$ Caderno de Pesquisas Trabalhistas. Porto Alegre: Lex Magister, 2017, p.12.
} 
ALMEIDA, Bruno Rotta; SALLET, Bruna Hoisler. Realidades prisionais e vulnerabilização étnica: aspectos sobre a questão indígena no sistema penitenciário brasileiro. Revista Eletrônica Direito e Política, Programa de Pós-Graduação Stricto Sensu em Ciência Jurídica da UNIVALI, Itajaí, v.13, n.3, $3^{\circ}$ quadrimestre de 2018. Disponível em: www.univali.br/direitoepolitica - ISSN 1980-7791

De acordo com dados colhidos no site da Câmara dos Deputados, todos os partidos políticos com representação casa legislativa apresentaram propostas de alteração da Consolidação das Leis do Trabalho, o que demonstra que havia uma demanda por mudanças represada e que a ânsia por reformas era generalizada, cabendo destacar que o partido do Movimento Democrático Brasileiro (MDB), por ter a maior bancada, apresentou o maior número de emendas, 264 ao todo, seguido pelo Partido Solidariedade (SD), Partido da República (PR), Partido Progressista (PP) e Partido da Social Democracia Brasileira (PSDB), que apresentaram mais de 100 emendas cada um.

Muitas são as causas desta explosão de emendas e substitutivos ao projeto de reforma da legislação trabalhista. Uma delas foi a estabilidade que a economia viveu a partir da edição do Plano Real, nos governos do Presidente Fernando Henrique Cardoso e no primeiro governo do Presidente Luiz Inácio Lula da Silva, visto que, nesses períodos a economia proporcionou bons resultados para os empregadores, reajustes salariais acima da inflação e pleno emprego, resultando em ambiente muito propício para a manutenção do status quo.

Outra causa foi a gradual ascensão do Partido dos Trabalhadores ao poder. Nas décadas de 1970 e 1980 os sindicatos eram os protagonistas dos principais movimentos populares por reformas políticas e sociais. À medida que o Partido dos Trabalhadores conquista posições nos poderes legislativo e Executivo os sindicatos deixam de liderar os movimentos populares e passam a se dedicar à articulação política para sustentação partidária, inclusive realizando alianças pragmáticas com partidos ideologicamente diferentes. Consequentemente, os sindicatos vão paulatinamente perdendo o encanto heroico que atraia os trabalhadores.

A partir do segundo governo do Presidente Lula, embora a economia e o emprego tivessem entrado em declínio, tínhamos no congresso uma aliança política eclética, integrada por partidos de esquerda, como o Partido dos Trabalhadores (PT), Partido Comunista do Brasil (PC do B), Partido Socialismo e Liberdade (PSOL), dentre outros, e também por partidos de centro e direita, com o partido do Movimento Democrático Brasileiro (MDB), o Partido Democratas (DEM), etc. Parte das forças políticas envolvidas nesta eclética coligação tinha interesse em reformar 
ALMEIDA, Bruno Rotta; SALLET, Bruna Hoisler. Realidades prisionais e vulnerabilização étnica: aspectos sobre a questão indígena no sistema penitenciário brasileiro. Revista Eletrônica Direito e Política, Programa de Pós-Graduação Stricto Sensu em Ciência Jurídica da UNIVALI, Itajaí, v.13, n.3, $3^{\circ}$ quadrimestre de 2018. Disponível em: www.univali.br/direitoepolitica - ISSN 1980-7791

a legislação trabalhista para aumentar o direito dos trabalhadores, e outra parte tinha interesse exatamente oposto, ou seja, conter o avanço dos direitos e encargos trabalhistas. Para não abalar o equilíbrio da coligação política as forças envolvidas acomodaram-se em um longo período de inércia, justamente para não fazer alterações profundas, nem em um sentido, nem noutro.

Também é relevante registrar que os governos do Partido dos Trabalhadores foram apoiados não só politicamente, mas também economicamente, por centrais sindicais, confederações, federações e sindicatos de trabalhadores, de maneira que as entidades sindicais transmitiram para o setor político o seu total desinteresse em discutir questões dogmáticas para as entidades sindicais, tais como a contribuição sindical obrigatória, unicidade sindical, representatividade sindical automática, base territorial, segregação por categorias, etc. As forças sindicais, tanto dos empregados quanto dos empregadores estavam acomodadas diante do protecionismo sindical, de maneira que não era politicamente conveniente nenhuma iniciativa legislativa que alterasse o status quo.

Depois de anos de marasmo, o desfazimento da aliança partidária que liderava a coalizão política, especialmente a ruptura do Partido dos Trabalhadores com o PMDB, atual MDB, ocorreu em paralelo com uma grave crise econômica que abalou a classe empresarial e alavancou o desemprego.

Em meio à crise econômica e política, os elementos impeditivos de uma reforma trabalhista deixaram de existir e após anos de letargia o projeto de lei do Poder Executivo deflagrou um debate legislativo tenso e avassalador, que resultou na rápida tramitação do projeto de lei da reforma trabalhista que recebeu o número PL 6787/2016 na Câmara dos Deputados e PLC 038/2017 no Senado Federal.

Independentemente da qualidade e do alinhamento com correntes políticas ou ideológicas o produto legislativo está aí: a Lei 13.467, de 13 de julho de 2017, que entrou em vigor em 11 de novembro de 2017.

Durante o processo legislativo da reforma trabalhista foram realizadas dezessete audiências públicas Câmara dos Deputados (para debater o PL 6787/2016) e outras cinco audiências públicas no Senado Federal (para debater o PLC 030/2017) 
ALMEIDA, Bruno Rotta; SALLET, Bruna Hoisler. Realidades prisionais e vulnerabilização étnica: aspectos sobre a questão indígena no sistema penitenciário brasileiro. Revista Eletrônica Direito e Política, Programa de Pós-Graduação Stricto Sensu em Ciência Jurídica da UNIVALI, Itajaí, v.13, n.3, $3^{\circ}$ quadrimestre de 2018. Disponível em: www.univali.br/direitoepolitica - ISSN 1980-7791

nas quais estiveram presentes sindicalistas representantes de empregados (Central Única dos Trabalhadores - CUT, Força Sindical, União Geral dos Trabalhadores - UGT, Central dos Sindicatos Brasileiros - CSB, Nova Central Sindical de Trabalhadores - NCST, Central dos Trabalhadores e Trabalhadoras do Brasil - CTB, Confederação Nacional dos Trabalhadores no Comércio - CNTC, Confederação Nacional dos Trabalhadores no Ramo Financeiro - CONTRAF, dentre outros), bem como, representantes de entidades sindicais patronais (Confederação Nacional da Indústria - CNI, Confederação Nacional do Comércio CNC, Confederação Nacional da Agricultura - CNA, Confederação Nacional do Setor Financeiro - CNF, Federação Nacional das Empresas de Informática FENAINFO, entre outros).

Também foram ouvidos nas audiências públicas muitos magistrados trabalhistas, inclusive ministros do Tribunal Superior do Trabalho (tais como Ives Gandra Martins Filho, Maurício Godinho Delgado, Walmir Oliveira da Costa e Alexandre de Souza Agra Belmonte), desembargadores (dentre eles Vólia Bonfim Cassar - TRT $1^{\text {a }}$ Região, João Bosco Pinto Lara - TRT $3^{a}$ Região, José Maria Quadros de Alencar - TRT 8a. Região, Bento Herculano Duarte Neto - TRT 21a. Região) representantes do Ministério Público do Trabalho, dos auditores fiscais, da advocacia, economistas, sociólogos, professores, dentre outros representantes de diversos setores da sociedade, proporcionando ao parlamento um debate de conteúdo técnico rico em subsídios jurídicos, econômicos e sociais.

Contudo, não é pacífico o entendimento a respeito da efetividade da participação da sociedade na reforma da legislação trabalhista. Deputados e Senadores ligados às corporações sindicais e aos movimentos sociais alegam que o "regime de urgência" concedido ao projeto de lei prejudicou os debates e que os argumentos técnicos apresentados aos parlamentares não foram devidamente debatidos e incorporados ao texto da norma. Alegam também que ao chegar ao Senado, a reforma trabalhista foi novamente analisada em "regime de urgência", com diminuto espaço para os debates, resultando no acatamento integral do texto produzido na Câmara dos Deputados. 
ALMEIDA, Bruno Rotta; SALLET, Bruna Hoisler. Realidades prisionais e vulnerabilização étnica: aspectos sobre a questão indígena no sistema penitenciário brasileiro. Revista Eletrônica Direito e Política, Programa de Pós-Graduação Stricto Sensu em Ciência Jurídica da UNIVALI, Itajaí, v.13, n.3, $3^{\circ}$ quadrimestre de 2018. Disponível em: www.univali.br/direitoepolitica - ISSN 1980-7791

Neste aspecto cabe lembrar a doutrina de Häberle, para quem uma sociedade aberta é aquela na qual o cidadão está inserido no processo de interpretação normativa: quem vive a norma acaba por interpretá-la. O jurista alemão não se limitou a defender a necessidade da participação do cidadão na interpretação da Constituição. Para ele a participação de indivíduos ou grupos qualificados, sob a influência da teoria democrática, deve acontecer também na elaboração das normas:

Assume idêntico relevo o papel co-interpretativo do técnico ou expert no âmbito do processo legislativo ou judicial. Essa complexa participação do intérprete em sentido lato e em sentido estrito realiza-se não apenas onde ela já está institucionalizada, como nos Tribunais do Trabalho, por parte do empregador e do empregado. Experts e "pessoas interessadas" da sociedade pluralista também se convertem em intérpretes do direito estatal. Isso significa que não apenas 0 processo de formação, mas também 0 desenvolvimento posterior, revela-se pluralista: a teoria da ciência, da democracia, uma teoria da Constituição e de hermenêutica propiciam aqui uma mediação específica entre Estado e sociedade. ${ }^{6}$

Em relação à reforma trabalhista não resta dúvida quanto à efetiva abertura dada pelo Poder Legislativo à participação social, da mesma forma que não restam dúvidas que os cidadãos que opinaram nas audiências públicas (alguns supra citados) enquadram-se perfeitamente nos conceitos de "experts" e "pessoas interessadas" utilizados por Häberle, não existindo nenhum espaço para questionamentos quanto a esse aspecto.

A crítica cabível é quanto ao aproveitamento, pelos membros do parlamento, do conhecimento e experiência expostos pelos experts, visto que as audiências públicas, nos termos do artigo 255 do Regimento Interno da Câmara dos

\footnotetext{
${ }^{6}$ HÄBERLE, Peter. Hermenêutica Constitucional. A Sociedade Aberta dos Intérpretes da Constituição: Contribuição para a interpretação pluralista e a "Procedimental" da Constituição. Porto Alegre: Sérgio Antônio Fabris Editor, 2002, p.17
} 
ALMEIDA, Bruno Rotta; SALLET, Bruna Hoisler. Realidades prisionais e vulnerabilização étnica: aspectos sobre a questão indígena no sistema penitenciário brasileiro. Revista Eletrônica Direito e Política, Programa de Pós-Graduação Stricto Sensu em Ciência Jurídica da UNIVALI, Itajaí, v.13, n.3, $3^{\circ}$ quadrimestre de 2018. Disponível em: www.univali.br/direitoepolitica - ISSN 1980-7791

Deputados $^{7}$ e do artigo 93 do Regimento Interno do Senado 8 não têm natureza deliberativa, mas consultiva, visando instruir matéria legislativa em trâmite ou tratar de assuntos de interesse público relevante.

Em uma das 17 (dezessete) audiências públicas realizadas na Câmara dos Deputados em Brasília para debater a reforma trabalhista, especificamente aquela ocorrida no dia 23 de março de 2017, um dos deputados presentes, Arolde de Oliveira $(P S D-R J)^{9}$, antes de fazer suas observações quanto o conteúdo das palestras, fez uma ponderação sobre a finalidade das audiências públicas que revela compreensão quanto à dimensão deste mecanismo de escuta técnica ou popular:

Eu sou um adepto da ampliação do conhecimento. O conhecimento na vida é tudo. Com conhecimento, você fundamenta os seus argumentos. A única perturbação ao conhecimento é a ideologia. A ideologia é dogmática e não aceita argumentação. Essa é a situação. Eu fico muito feliz por ter ouvido aulas e palestras e por poder ampliar o meu conhecimento na área jurídica, que não é a minha. Eu sou engenheiro e economista [...] Neste momento, fico feliz de ouvir o Ministro Maurício ${ }^{10}$ e o desembargador João Bosco ${ }^{11}$ fazerem suas considerações. Sinto que eu sintonizo com esses pontos de vista.

Assim, a incorporação ou não das manifestações feitas nas audiências públicas depende de uma deliberação coletiva do parlamento a ser tomada posteriormente durante as votações nas comissões temáticas ou no plenário das casas legislativas. Considerando que os membros do parlamento, como seres políticos, têm suas

\footnotetext{
7 BRASIL. Resolução n. 17, de 1989 da Câmara dos Deputados. Aprova o Regimento Interno. Disponível em: http://bd.camara.gov.br/bd/handle/bdcamara/18847. Acesso em: 10. set. 2017

8 BRASIL. Resolução n. 93, de 1970 do Senado Federal. Aprova o Regimento Interno. Disponível em: http://www25.senado.leg.br/web/atividade/regimento-interno. Acesso em: $1^{0}$. set. 2017

9 OLIVEIRA, Arolde de. Discurso proferido em audiência pública realizada em 23/03/2017 na Câmara dos Deputados. Brasília: 2017. Disponível em: http://www2.camara.leg.br/atividadelegislativa/comissoes/comissoes-temporarias/especiais/55a-legislatura/pl-6787-16-reformatrabalhista/documentos/notas-taquigraficas/NT13ROAP230317.pdf. Acesso em 02 set. 2017

${ }^{10}$ Referiu-se a Maurício Godinho Delgado, ministro do Tribunal Superior do Trabalho, que participou da audiência pública realizada em 23.03.2017 na Câmara dos Deputados para debater a reforma trabalhista.

11 Referiu-se a João Bosco Pinto Lara, desembargador do Tribunal Regional do Trabalho da $3^{a}$. Região que participou da audiência pública acima mencionada.
} 
ALMEIDA, Bruno Rotta; SALLET, Bruna Hoisler. Realidades prisionais e vulnerabilização étnica: aspectos sobre a questão indígena no sistema penitenciário brasileiro. Revista Eletrônica Direito e Política, Programa de Pós-Graduação Stricto Sensu em Ciência Jurídica da UNIVALI, Itajaí, v.13, n.3, $3^{\circ}$ quadrimestre de 2018. Disponível em: www.univali.br/direitoepolitica - ISSN 1980-7791

preferências e compromissos ideológicos, nem sempre a decisão a ser tomada é uma decisão técnica (para não dizer frequentemente) como alertado pelo deputado federal Arolde de Oliveira no trecho do discurso que foi acima reproduzido.

As audiências públicas realizadas para discutir a reforma trabalhista, embora não vinculem o legislador, cumpriram o importante papel de conecta-lo com a sociedade civil, proporcionando inclusões, supressões ou alterações de artigos no texto que posteriormente foi votado e aprovado pelo Congresso Nacional.

O testemunho da atuação dos experts na elaboração da Lei 13.467/2017 está na Nota da Editora Forense à obra da desembargadora, agora aposentada, Vólia Bomfim: "A obra é organizada pela Desembargadora Vólia Bomfim Cassar, que participou ativamente das discussões sobrea a Reforma Trabalhista e traz comentários da organizadora ao texto reformado ${ }^{12} . "$

\section{PAPEL DOS SINDICATOS}

Uma primeira leitura do artigo 511 da Consolidação das Leis do Trabalho nos transmite uma ideia de atuação limitada das entidades sindicais nas questões ligadas aos interesses econômicos e profissionais da categoria:

Art. 511. É lícita a associação para fins de estudo, defesa e coordenação dos seus interesses econômicos ou profissionais de todos os que, como empregadores, empregados, agentes ou trabalhadores autônomos ou profissionais liberais exerçam, respectivamente, a mesma atividade ou profissão ou atividades ou profissões similares ou conexas. ${ }^{13}$

A partir de 1988 a Constituição da República alargou o escopo sindical previsto na lei ordinária, tendo em vista que não restringiu a atuação do sindicato aos interesses econômicos ou profissionais:

\footnotetext{
12 CASSAR, Vólia Bomfim. CLT Comparada e Atualizada com a Reforma Trabalhista. São Paulo: Forense, 2018, Nota da Editora.
}

13 BRASIL. Decreto-Lei 5.452, de $1^{\circ}$ de maio de 1943. Aprova a Consolidação das Leis do Trabalho. Disponível em: http://www.planalto.gov.br/ccivil_03/decreto-lei/Del5452.htm. Acesso em 02 de set. 2017 
ALMEIDA, Bruno Rotta; SALLET, Bruna Hoisler. Realidades prisionais e vulnerabilização étnica: aspectos sobre a questão indígena no sistema penitenciário brasileiro. Revista Eletrônica Direito e Política, Programa de Pós-Graduação Stricto Sensu em Ciência Jurídica da UNIVALI, Itajaí, v.13, n.3, $3^{\circ}$ quadrimestre de 2018. Disponível em: www.univali.br/direitoepolitica - ISSN 1980-7791

\author{
Art. $8^{\circ}$ É livre a associação profissional ou sindical, \\ observado o seguinte: (...)
}

III - ao sindicato cabe a defesa dos direitos e interesses coletivos ou individuais da categoria, inclusive em questões judiciais ou administrativas; (BRASIL, 1988). ${ }^{14}$

A Constituição de 1988, além de não limitar a atuação a questões profissionais e econômicas, conferiu aos sindicatos de âmbito nacional o importante instrumento para a defesa dos direitos e interesses da categoria, qual seja, a possibilidade de propor ação direta de inconstitucionalidade, conforme se vê no artigo 103, inciso IX, da Constituição da República.

A despeito das prescrições legais sobre o papel das entidades sindicais não revelarem grandes dimensões, o jurista Arnaldo Süssekind ${ }^{15}$ já defendia a abertura da atuação sindical. Com muita propriedade, relata que os sindicatos surgiram com a finalidade de obter, por meios conflituosos (reivindicações, negociações coletivas e greves) a melhoria das condições de trabalho, mas, com o tempo, os sindicatos poderiam deixar de atuar apenas em contraposição aos empregadores diretos e também poderiam se transformar em uma poderosa ferramenta para reformas econômicas, sociais e políticas. Süssekind aponta a doutrina de Vasquez Vialard ${ }^{16}$ no sentido de que os sindicatos devem primeiramente consolidar sua estrutura institucional mas não devem se limitar aos aspectos relacionados diretamente com o trabalho ou com as condições de trabalho, pois também devem expressar o desejo dos trabalhadores no concernente aos diversos aspectos do futuro nacional: político, econômico, cultural, etc. E conclui alertando que a atuação política do sindicato deve "dizer respeito a doutrinas ou ideologias políticas e não à prática de atos peculiares aos partidos políticos".

14 BRASIL. Constituição da República Federativa do Brasil, 1988. Disponível em: https://www.planalto.gov.br/ccivil_03/Constituicao/ConstituicaoCompilado.htm. Acesso em: 02 set. 2017

15 SÜSSEKIND, Arnaldo. Direito Constitucional do Trabalho. Rio de Janeiro: Renovar, 2001, p.335.

16 VIALARD, Antônio Vasquez. Derecho del Trabajo y Seguridad Social. Buenos Aires: Depalma, 1981, p. 178. 
ALMEIDA, Bruno Rotta; SALLET, Bruna Hoisler. Realidades prisionais e vulnerabilização étnica: aspectos sobre a questão indígena no sistema penitenciário brasileiro. Revista Eletrônica Direito e Política, Programa de Pós-Graduação Stricto Sensu em Ciência Jurídica da UNIVALI, Itajaí, v.13, n.3, $3^{\circ}$ quadrimestre de 2018. Disponível em: www.univali.br/direitoepolitica - ISSN 1980-7791

No Brasil atual, sob a égide da Constituição de 1988, a atuação dos sindicatos foi muito além do que lecionava Süssekind de maneira que a atuação política dos sindicatos atingiu as estruturas de poder, penetrou nos quadros de partidos políticos e criou redes de relacionamento e apoio recíproco com movimentos sociais ligados ao meio ambiente, a reforma agrária, a moradia urbana, a educação, dentre outros, engajados em um processo de transformação social.

Os sindicatos ganharam capilaridade política a partir do momento em que conectaram suas "bandeiras" com as " bandeiras" de outros segmentos. O poder de articulação dos sindicatos possibilitou a eleição de uma significativa bancada de parlamentares, principalmente do Partido dos Trabalhos (PT), bem como a eleição do Presidente Luiz Inácio Lula da Silva e de sua sucessora Dilma Rousseff.

O impeachment da Presidente Rousseff e o envolvimento do governo petista em escândalos de corrupção diminuíram o poder político dos sindicatos, mas eles ainda conservam a estrutura institucional que Ihes aparelha para influenciar, não só, as atividades políticas, mas também as atividades genuinamente sindicais: as negociações coletivas.

O desgaste da imagem da classe política sindical - nivelada por baixo com a imagem dos políticos tradicionais precedentes - sugere um retorno dos sindicatos às origens e à missão original de servir ao trabalhador, utilizando os mecanismos da nova legislação para, quem sabe, reconstruir um novo ciclo de poder.

\section{A NOVA NEGOCIAÇÃO COLETIVA}

A primeira mensagem que a Lei 13.467/2017 transmite é a da valorização da negociação coletiva através da sua classificação como negócio jurídico e do estabelecimento do "princípio da intervenção mínima na autonomia da vontade coletiva, pelo Poder Judiciário. É o que se colhe da nova redação do artigo oitavo, parágrafo terceiro, da Consolidação das Leis do Trabalho:

Art. 80. $[\ldots]$

§ 30 No exame de convenção coletiva ou acordo coletivo de trabalho, a Justiça do Trabalho analisará exclusivamente a conformidade dos elementos essenciais do negócio jurídico, 
ALMEIDA, Bruno Rotta; SALLET, Bruna Hoisler. Realidades prisionais e vulnerabilização étnica: aspectos sobre a questão indígena no sistema penitenciário brasileiro. Revista Eletrônica Direito e Política, Programa de Pós-Graduação Stricto Sensu em Ciência Jurídica da UNIVALI, Itajaí, v.13, n.3, 30 quadrimestre de 2018. Disponível em: www.univali.br/direitoepolitica - ISSN 1980-7791

respeitado o disposto no art. 104 da Lei no 10.406 , de 10 de janeiro de 2002 (Código Civil), e balizará sua atuação pelo princípio da intervenção mínima na autonomia da vontade coletiva. ${ }^{17}$

E para operacionalizar a atuação de sindicatos e empresas, no curso das negociações, a Lei 13.467/2017 delimitou o que pode ser negociado e o que não pode ser negociado, respectivamente nos artigos 611-A e 611-B da Consolidação das Leis do Trabalho, abaixo transcritos:

Art. 611-A. A convenção coletiva e o acordo coletivo de trabalho têm prevalência sobre a lei quando, entre outros, dispuserem sobre:

I - pacto quanto à jornada de trabalho, observados os limites constitucionais;

II - banco de horas anual;

III - intervalo intrajornada, respeitado o limite mínimo de trinta minutos para jornadas superiores a seis horas;

V - adesão ao Programa Seguro-Emprego (PSE), de que trata a Lei no 13.189, de 19 de novembro de 2015;

V - plano de cargos, salários e funções compatíveis com a condição pessoal do empregado, bem como identificação dos cargos que se enquadram como funções de confiança;

VI - regulamento empresarial;

VII - representante dos trabalhadores no local de trabalho;

VIII - teletrabalho, regime de sobreaviso, e trabalho intermitente;

IX - remuneração por produtividade, incluídas as gorjetas percebidas pelo empregado, e remuneração por desempenho individual;

$\mathrm{X}$ - modalidade de registro de jornada de trabalho;

XI - troca do dia de feriado;

XII - enquadramento do grau de insalubridade;

XIII - prorrogação de jornada em ambientes insalubres, sem licença prévia das autoridades competentes do Ministério do Trabalho;

XIV - prêmios de incentivo em bens ou serviços, eventualmente concedidos em programas de incentivo; XV - participação nos lucros ou resultados da empresa.

17 BRASIL. Lei no 13.467, de 13 de julho de 2017. Altera a Consolidação das Leis do Trabalho (CLT) e as Leis nos 6.019/1974, 8.036/1990, e 8.212/1991. Disponível em: http://www.planalto.gov.br/ccivil_03/_Ato2015-2018/2017/Lei/L13467.htm. Acesso em 02 jan. 2018. 
ALMEIDA, Bruno Rotta; SALLET, Bruna Hoisler. Realidades prisionais e vulnerabilização étnica: aspectos sobre a questão indígena no sistema penitenciário brasileiro. Revista Eletrônica Direito e Política, Programa de Pós-Graduação Stricto Sensu em Ciência Jurídica da UNIVALI, Itajaí, v.13, n.3, $3^{\circ}$ quadrimestre de 2018. Disponível em: www.univali.br/direitoepolitica - ISSN 1980-7791

\section{$[\ldots]$}

Art. 611-B. Constituem objeto ilícito de convenção coletiva ou de acordo coletivo de trabalho, exclusivamente, a supressão ou a redução dos seguintes direitos:

I - normas de identificação profissional, inclusive as anotações na Carteira de Trabalho e Previdência Social;

II - seguro-desemprego, em caso de desemprego involuntário;

III - valor dos depósitos mensais e da indenização rescisória do Fundo de Garantia do Tempo de Serviço (FGTS);

IV - salário mínimo;

V - valor nominal do décimo terceiro salário;

VI - remuneração do trabalho noturno superior à do diurno;

VII - proteção do salário na forma da lei, constituindo crime sua retenção dolosa;

VIII - salário-família;

IX - repouso semanal remunerado;

$X$ - remuneração do serviço extraordinário superior, no mínimo, em 50\% (cinquenta por cento) à do normal;

XI - número de dias de férias devidas ao empregado;

XII - gozo de férias anuais remuneradas com, pelo menos, um terço a mais do que o salário normal;

XIII - licença-maternidade com a duração mínima de cento e vinte dias;

XIV - licença-paternidade nos termos fixados em lei;

XV - proteção do mercado de trabalho da mulher, mediante incentivos específicos,

nos termos da lei;

XVI - aviso prévio proporcional ao tempo de serviço, sendo no mínimo de trinta dias, nos termos da lei;

XVII - normas de saúde, higiene e segurança do trabalho previstas em lei ou em normas regulamentadoras do Ministério do Trabalho;

XVIII - adicional de remuneração para as atividades penosas, insalubres ou perigosas;

XIX - aposentadoria;

XX - seguro contra acidentes de trabalho, a cargo do empregador;

XXI - ação, quanto aos créditos resultantes das relações de trabalho, com prazo prescricional de cinco anos para os trabalhadores urbanos e rurais, até o limite de dois anos após a extinção do contrato de trabalho;

XXII - proibição de qualquer discriminação no tocante a salário e critérios de admissão do trabalhador com deficiência; XXIII - proibição de trabalho noturno, perigoso ou insalubre a menores de dezoito anos e de qualquer trabalho a menores de dezesseis anos, salvo na condição de aprendiz, a partir de quatorze anos;

XXIV - medidas de proteção legal de crianças e adolescentes; 
ALMEIDA, Bruno Rotta; SALLET, Bruna Hoisler. Realidades prisionais e vulnerabilização étnica: aspectos sobre a questão indígena no sistema penitenciário brasileiro. Revista Eletrônica Direito e Política, Programa de Pós-Graduação Stricto Sensu em Ciência Jurídica da UNIVALI, Itajaí, v.13, n.3, $3^{\circ}$ quadrimestre de 2018. Disponível em: www.univali.br/direitoepolitica - ISSN 1980-7791

XXV - igualdade de direitos entre o trabalhador com vínculo empregatício permanente e o trabalhador avulso;

XXVI - liberdade de associação profissional ou sindical do trabalhador, inclusive o direito de não sofrer, sem sua expressa e prévia anuência, qualquer cobrança ou desconto salarial estabelecidos em convenção coletiva ou acordo coletivo de trabalho;

XXVII - direito de greve, competindo aos trabalhadores decidir sobre a oportunidade de exercê-lo e sobre os interesses que devam por meio dele defender;

XXVIII - definição legal sobre os serviços ou atividades essenciais e disposições legais sobre o atendimento das necessidades inadiáveis da comunidade em caso de greve;

XXIX - tributos e outros créditos de terceiros;

XXX - as disposições previstas nos arts. 373-A, 390, 392, 392A, 394, 394-A, 395, 396 e 400 desta Consolidação. ${ }^{18}$

É relevante observar que o rol de proibições é muito mais longo do que o rol de permissões. Enquanto o primeiro contempla quinze temas, o segundo contempla trinta e nove temas (considerando que o inciso XXX do artigo 611-B abrange matérias previstas em nove artigos da CLT).

Por que, então, tendo em vista que o rol de proibições é maior do que o rol de permissões, a negociação coletiva estaria prestigiada na reforma trabalhista?

A resposta está justamente na transparência da norma que possibilita conhecer os limites da negociação coletiva: saber previamente o que pode ser negociado e o que não pode, o que, em última instância, é traduzido em segurança jurídica.

Muitos dos temas elencados têm sido objeto de disputas jurídicas, dentre as quais ações anulatórias de cláusulas de acordos coletivos de trabalho movidas pelo Ministério Público do Trabalho. Também não são raros os casos nos quais uma das partes signatárias do acordo coletivo de trabalho, de forma absolutamente absurda e deliberada, firma um instrumento jurídico com inúmeras cláusulas e, em seguida, ajuíza ações questionando a cláusula que não Ihe interessa, embora o Judiciário

\footnotetext{
${ }^{18}$ BRASIL. Lei no 13.467, de 13 de julho de 2017. Altera a Consolidação das Leis do Trabalho (CLT) e as Leis 6.019/1974, 8.036/1990, e 8.212/1991. Disponível em: http://www.planalto.gov.br/ccivil_03/_Ato2015-2018/2017/Lei/L13467.htm. Acesso em 02 jan. 2018.
} 
ALMEIDA, Bruno Rotta; SALLET, Bruna Hoisler. Realidades prisionais e vulnerabilização étnica: aspectos sobre a questão indígena no sistema penitenciário brasileiro. Revista Eletrônica Direito e Política, Programa de Pós-Graduação Stricto Sensu em Ciência Jurídica da UNIVALI, Itajaí, v.13, n.3, $3^{\circ}$ quadrimestre de 2018. Disponível em: www.univali.br/direitoepolitica - ISSN 1980-7791

geralmente coíba este tipo de demanda ardilosa, conforme se vê na decisão, parcialmente reproduzida abaixo, proferida pelo Tribunal Superior do Trabalho:

A determinação de aplicação da multa do artigo 18 do CPC pela litigância de má-fé decorreu por ter se verificado a existência de recurso infundado e protelatório, diante da contradição do Sindicato Reclamado de atacar cláusula de norma coletiva por ele próprio firmada. Tal decisão não viola diretamente os artigos. 50, XXXV, e 8० , III, da CF, já que não impediu o acesso do Sindicato ao Poder Judiciário, nem impediu a sua atuação na defesa dos direitos e interesses da categoria $[\ldots]^{19}$

É elogiável a decisão acima transcrita, mas há casos nos quais o Tribunal Superior do Trabalho não atuou em favor da segurança jurídica, restando ao Supremo Tribunal Federal exercer a poder de revisão constitucional, como se vê, por exemplo, no caso do julgamento da ação de Arguição de Descumprimento de Preceito Fundamental n. $323{ }^{20}$ que resultou na suspensão liminar da Súmula 277 do Tribunal Superior do Trabalho, e ainda, no julgamento da Recurso Ordinário que reconheceu a autonomia coletiva dos sindicatos, conforme se vê no trecho do voto proferido pelo Ministro Luís Roberto Barroso abaixo transcrito:

Não socorre a causa dos trabalhadores a afirmação constante do acórdão do TST que uniformizou o entendimento sobre a matéria, de que "o empregado merece proteção, inclusive, contra a sua própria necessidade ou ganância. ${ }^{21}$ Não se pode tratar como absolutamente incapaz e inimputável para a vida civil toda uma categoria profissional, em detrimento do explícito reconhecimento constitucional de sua autonomia coletiva (art. 70, XXVI, CF). As normas paternalistas, que podem ter seu valor no âmbito do direito individual, são as mesmas que atrofiam a capacidade participativa do trabalhador no âmbito coletivo e que amesquinham a sua contribuição para a solução dos problemas que o afligem. É através do respeito aos acordos negociados coletivamente que os trabalhadores poderão compreender e aperfeiçoar a sua capacidade de mobilização e de conquista, inclusive de

19 BRASIL. TST. Tribunal Superior do Trabalho. Recurso de Revista no TST-RR-1700058.2007.5.01.0343. Acórdão publicado em 16/09/2013

20 BRASIL. STF. Supremo Tribunal Federal. Arguição de Descumprimento de Preceito Fundamental n. 323. Decisão cautelar proferida pelo Ministro Gilmar Mendes em 14/10/2016

21 Referëncia ao julgamento do Processo n. TST-ROAA-1115/2002-000-12-00.6, rel. min. José Luciano de Castilho Pereira, SDC, publicado no DJe, 16/03/2007. 
ALMEIDA, Bruno Rotta; SALLET, Bruna Hoisler. Realidades prisionais e vulnerabilização étnica: aspectos sobre a questão indígena no sistema penitenciário brasileiro. Revista Eletrônica Direito e Política, Programa de Pós-Graduação Stricto Sensu em Ciência Jurídica da UNIVALI, Itajaí, v.13, n.3, $3^{\circ}$ quadrimestre de 2018. Disponível em: www.univali.br/direitoepolitica - ISSN 1980-7791

forma a defender a plena liberdade sindical. Para isso é preciso, antes de tudo, respeitar a sua voz. ${ }^{22}$

Está claro que o objetivo das alterações legislativas foi dotar os sindicatos e empresas de uma ferramenta jurídica mais objetiva que, se for bem manejada, contribuirá para que as relações trabalhistas sejam exercidas de forma mais segura e produtiva, com menor espaço para surpresas e reviravoltas judiciais.

Muito embora seja preocupante a crítica que se faz à qualificação das entidades sindicais para atuação negocial em prol das categorias de trabalhadores que eles representam, deve ser considerado que a evolução dos interlocutores depende do efetivo exercício das negociações e, desta forma, não será o alijamento dos sindicatos da relação direta com os patrões que os transformará em eficazes negociadores.

O ideal seria que a estrutura sindical brasileira ganhasse contornos semelhantes aos dos países economicamente mais desenvolvidos onde existem poucos sindicatos, mas com representatividade e aparelhamento suficientes para a defesa dos interesses dos trabalhadores.

Segundo pesquisa de André Gambier Campos, do Instituto de Pesquisas Econômicas Aplicadas (IPEA), no Brasil existiam 16.491 entidades sindicais, sendo 5.251 de empregadores e 11.240 de empregados. ${ }^{23}$ A consequência imediata de um número tão elevado é a enorme fragmentação territorial, de maneira que $50,1 \%$ dos sindicatos brasileiros têm base territorial municipal e outros 30,3\% têm uma base territorial com um pequeno número de municípios. Apenas $1,1 \%$ dos sindicatos de trabalhadores têm base interestadual ou nacional.

Nem por isso o índice de engajamento sindical dos trabalhadores é mais elevado. A atuação local, hoje majoritária, não tem permitido que os dirigentes sindicais

\footnotetext{
22 BRASIL. STF. Supremo Tribunal Federal. Recurso Extraordinário 590.415. Relator Ministro Roberto Barroso. Julgado em 30/04/2015

23 CAMPOS, André Gambier. Sindicatos no Brasil: O que esperar no futuro próximo? Repositório do Conhecimento do IPEA, Rio de Janeiro, dez 2016, p.9. Disponível em: http://repositorio.ipea.gov.br/handle/11058/7353. Acesso em 02 set. 2017.
} 
ALMEIDA, Bruno Rotta; SALLET, Bruna Hoisler. Realidades prisionais e vulnerabilização étnica: aspectos sobre a questão indígena no sistema penitenciário brasileiro. Revista Eletrônica Direito e Política, Programa de Pós-Graduação Stricto Sensu em Ciência Jurídica da UNIVALI, Itajaí, v.13, n.3, $3^{\circ}$ quadrimestre de 2018. Disponível em: www.univali.br/direitoepolitica - ISSN 1980-7791

tenham uma maior proximidade e interlocução com os trabalhadores, como evidenciam os números apurados pelo IPEA: apenas 20,3\% dos trabalhadores registrados em empresas privadas filiaram-se espontaneamente a um sindicato. ${ }^{24}$

A principal causa do caos sindical existente hoje no Brasil não será solucionada pelas alterações introduzidas recentemente pel Lei $13.467 / 2017$, porque decorre de comando constitucional: a unicidade sindical.

Conforme sábia reflexão de Süssekind, as circunstâncias sociais que justificaram a adoção da unicidade sindical na década de 1940 há muito tempo não existem mais, tampouco o efeito esperado de se evitar a fragmentação da representação profissional:

Nós, tal como os demais integrantes da comissão elaboradora do projeto da CLT, já defendemos o monopólio de representação sindical, à época imposto pela Carta Política de 1937. Justificamos, assim, que GETÚLIO VARGAS o tenha adotado visando a evitar o fracionamento dos sindicatos e o consequente enfraquecimento das respectivas representações, numa época em que o espírito sindical dificultava a formação de organismos sindicais e a filiação dos trabalhadores aos mesmos. Afinal, esse espírito resulta das concentrações operárias, que dependem do desenvolvimento industrial. Daí por que, hoje, defendemos a liberdade de constituição de sindicatos, embora reconhecendo que o ideal seja a unicidade de representação decorrente da conscientização dos grupos de trabalhadores ou de empresários interligados por uma atividade comum. ${ }^{25}$

A união dos trabalhadores pretendida por Süssekind, tão livre quanto consciente, pode ser percebida na América do Norte, com o exemplo do United Steelworkers, entidade sindical estabelecida em uma jurisdição onde não existe unicidade sindical nem filiação sindical obrigatória, mas que representa 850.000 mil trabalhadores espalhados por 1.800 local unions do Canadá, Estados Unidos e Caribe.

${ }^{24}$ CAMPOS, André Gambier. Sindicatos no Brasil: O que esperar no futuro próximo?, p.12.

25 SÜSSEKIND, Arnaldo. Curso de Direito do Trabalho. Rio de Janeiro: Renovar, 2002, p. 529. 
ALMEIDA, Bruno Rotta; SALLET, Bruna Hoisler. Realidades prisionais e vulnerabilização étnica: aspectos sobre a questão indígena no sistema penitenciário brasileiro. Revista Eletrônica Direito e Política, Programa de Pós-Graduação Stricto Sensu em Ciência Jurídica da UNIVALI, Itajaí, v.13, n.3, $3^{\circ}$ quadrimestre de 2018. Disponível em: www.univali.br/direitoepolitica - ISSN 1980-7791

Haverá uma grande evolução do sindicalismo brasileiro no momento em que, a despeito dos interesses individuais ou partidários, os sindicatos buscarem o fortalecimento dos trabalhadores através da fusão de categorias. Em uma economia globalizada, onde empresas atuam em redes internacionais não é razoável que a grande maioria dos sindicatos ainda atue localmente.

Diante das dificuldades para as fusões sindicais, que tendem a ocorrer em um espaço mais largo de tempo, é possível vislumbrar outras alternativas para o fortalecimento dos sindicatos profissionais. Uma delas, muito utilizada no Brasil, é a atuação através das Federações e Confederações de trabalhadores para a celebração de convenções coletivas de abrangência nacional. É o que se vê, por exemplo, no caso dos setores bancário e petroleiro.

Outra alternativa, é a atuação de sindicatos em rede, copiando um modelo tipicamente empresarial, visando a celebração de um acordo coletivo (com uma empresa específica), independentemente de suas preferências partidárias ou de suas filiações a uma das sete centrais sindicais em operação. Um exemplo dessa atuação em rede é a que se dá entre os sindicatos que representam os trabalhadores em mineração, em ferrovias e técnicos industriais da mineradora Vale S.A. abrangendo tais categorias nos estados de Minas Gerais, Rio de Janeiro, Espírito Santo, Pará, Maranhão e Mato Grosso do Sul, visando um melhor posicionamento para a negociação de um acordo coletivo com a empresa.

A atuação conjunta, envolvendo maior número de trabalhadores, categorias e localidades dá aos sindicatos maior poder de mobilização, proporciona maior troca de experiências para análise de situações indesejadas que demandem atuação preventiva, bem como, maior visão geral das potencialidades da empresa para a concessão de cláusulas sociais e econômicas.

Neste aspecto, não se trata de inventar uma nova acepção para os sindicatos mas resgatar o papel original de engajamento dos trabalhadores para permitir um posicionamento fortalecido na interlocução com as empresas empregadoras.

Mas, surge a indagação: se a fusão ou formação de redes de sindicatos de trabalhadores fortalece as categorias profissionais e o movimento sindical, haveria, 
ALMEIDA, Bruno Rotta; SALLET, Bruna Hoisler. Realidades prisionais e vulnerabilização étnica: aspectos sobre a questão indígena no sistema penitenciário brasileiro. Revista Eletrônica Direito e Política, Programa de Pós-Graduação Stricto Sensu em Ciência Jurídica da UNIVALI, Itajaí, v.13, n.3, $3^{\circ}$ quadrimestre de 2018. Disponível em: www.univali.br/direitoepolitica - ISSN 1980-7791

como consequência, o enfraquecimento das empresas nas negociações coletivas? Não necessariamente. Depende da forma como a empresa encara a negociação coletiva e a própria relação capital-trabalho. Em uma negociação coletiva com maior amplitude, envolvendo um maior número de trabalhadores, de categorias e de localidades onde a empresa atua, tem-se a oportunidade de estabelecer normas laborais de forma mais estruturada e padronizada. Há também um reflexo positivo no clima organizacional e na administração rotineira do pessoal, pois evita que os trabalhadores de uma categoria ou localidade façam comparações e pleitos individualizados baseados no que foi concedido para outra categoria ou unidade operacional da empresa. A empresa evita ainda que as concessões feitas para um sindicato local se transformem em piso de reivindicações de outro sindicato local. A negociação com escopo mais amplo de trabalhadores tira a empresa da posição defensiva tornando-a mais receptiva às reivindicações sindicais, pois ela perde o receio de repercussões de um determinado acordo coletivo em outros acordos sindicais (de diferentes localidades ou categorias).

Acordos coletivos robustos que tenham cláusulas benéficas e relevantes para ambas as partes são muito mais propensos à renovação, visto que o impasse não interessa a nenhum dos lados, logo tendem a diminuir a necessidade de delegação da solução de conflitos ao Poder Judiciário.

Nesse aspecto, importante destacar que a Lei $13.467 / 2017$ alterou o $\S 3^{\circ}$ do artigo 614 da Consolidação das Leis do Trabalho e expressamente previu que "não será permitido estipular duração de convenção coletiva ou acordo coletivo de trabalho superior a dois anos, sendo vedada a ultratividade". Trata-se de uma evidente reação à atuação legiferante do Tribunal Superior do Trabalho que em 2009 alterou radicalmente a Súmula 277 e adotou o entendimento de que as cláusulas dos acordos coletivos ou convenções coletivas "integram os contratos individuais de trabalho e somente poderão ser modificadas ou suprimidas mediante negociação coletiva. "

Não se pode olvidar que a adoção da ultratividade da norma coletiva decorreu de uma justificada preocupação da Justiça do Trabalho. Isso porque, a Emenda Constitucional no 45, de 30 de dezembro de 2004, alterou o artigo 114, § 20, da 
ALMEIDA, Bruno Rotta; SALLET, Bruna Hoisler. Realidades prisionais e vulnerabilização étnica: aspectos sobre a questão indígena no sistema penitenciário brasileiro. Revista Eletrônica Direito e Política, Programa de Pós-Graduação Stricto Sensu em Ciência Jurídica da UNIVALI, Itajaí, v.13, n.3, $3^{\circ}$ quadrimestre de 2018. Disponível em: www.univali.br/direitoepolitica - ISSN 1980-7791

Constituição da República que rege a competência da Justiça do Trabalho, e passou a exigir que o dissídio coletivo seja requerido de comum acordo pelas partes que negociam um instrumento coletivo de trabalho:

Recusando-se qualquer das partes à negociação coletiva ou à arbitragem, é facultado às mesmas, de comum acordo, ajuizar dissídio coletivo de natureza econômica, podendo a Justiça do Trabalho decidir o conflito, respeitadas as disposições mínimas legais de proteção ao trabalho, bem como as convencionadas anteriormente. ${ }^{26}$

Em decorrência da alteração constitucional acima transcrita, a Justiça do Trabalho, decidiu alterar a Súmula 277 para criar uma alternativa para o impasse negocial. Se não há a celebração do acordo coletivo, nem há possibilidade do ajuizamento de dissídio coletivo, o Tribunal Superior do Trabalho entendeu que seria justo que o acordo ou convenção coletiva anteriormente celebrado passasse a vigorar por prazo indeterminado até que um novo instrumento coletivo viesse a ser celebrado.

A alteração sumular parecia justa, porém não foi desprovida de efeitos colaterais. A ultratividade da norma coletiva tornou-se um fator inibidor das negociações coletivas justamente nos períodos de maior prosperidade das empresas, quando há maior potencial de atendimento aos pleitos dos trabalhadores. E a razão é o receio que os empregadores têm em conceder vantagens possíveis em momento de pujança econômica e ter que arcar com os ônus de tais avanços também em tempos de crise, tendo em vista que elas restarão incorporadas aos contratos de trabalho, só podendo ser suprimidas por uma nova negociação coletiva. E aí seria a vez dos sindicatos dos trabalhadores se recusarem à negociação pretendida pela empresa para exclusão ou diminuição de benefícios, porque o impasse resultará na manutenção por prazo indeterminado das cláusulas em debate e porque os sindicatos, sabedores da necessidade do "comum acordo" para o dissídio coletivo, não permitirão a judicialização.

Cabe observar que o modelo atual, no qual a ultratividade da norma coletiva está conectada com o requisito do duplo acordo para os dissídios coletivos, aumenta a

26 BRASIL. Constituição da República Federativa do Brasil, 1988. Disponível em: https://www.planalto.gov.br/ccivil_03/Constituicao/ConstituicaoCompilado.htm. Acesso em: 02 set. 2017. 
ALMEIDA, Bruno Rotta; SALLET, Bruna Hoisler. Realidades prisionais e vulnerabilização étnica: aspectos sobre a questão indígena no sistema penitenciário brasileiro. Revista Eletrônica Direito e Política, Programa de Pós-Graduação Stricto Sensu em Ciência Jurídica da UNIVALI, Itajaí, v.13, n.3, $3^{\circ}$ quadrimestre de 2018. Disponível em: www.univali.br/direitoepolitica - ISSN 1980-7791

responsabilidade dos sindicatos e empresas nas negociações coletivas porque tornam estreita a porta da intervenção estatal.

Em contrapartida, a redação atual dos artigos 611-A e 611-B da Consolidação das Leis do Trabalho, dada pela Lei 13.467/2017, tornou mais largas as portas para a auto composição, através de critérios mais claros e seguros para a celebração de acordos coletivos e convenções coletivas de trabalho.

\section{CONSIDERAÇÕES FINAIS}

A reforma trabalhista, introduzida pela Lei $13.467 / 2017$ tem, como efeito imediato, a insegurança própria dos processos de transição, mas, em um segundo momento, com o apoio do Judiciário Trabalhista para a elucidação dos pontos mais polêmicos, trará a maior estabilidade e segurança jurídica desejadas por empregados, empregadores e governo.

A reforma foi necessária porque a legislação trabalhista estava desatualizada. Isso porque à medida que as relações capital-trabalho se tornaram mais dinâmicas (após a década de 1970), contraditoriamente, o processo legislativo para atualização da Consolidação das Leis do Trabalho tornou-se menos dinâmico.

Justamente em razão da desatualização da Consolidação das Leis do Trabalho o Tribunal Superior do Trabalho ocupou o espaço legislativo através da edição de quase 1.300 súmulas, enunciados e precedentes normativos.

Legislação desatualizada e a exagerada atuação legiferante da Justiça do Trabalho foram os principais fatores responsáveis pela insegurança jurídica nas relações trabalhistas e motivaram a sociedade, através do parlamento, a elaborar uma reforma na legislação trabalhista que pudesse se contrapor a esses dois fatores. Trata-se, portanto, de uma evidente reação da sociedade e do Congresso Nacional à insegurança jurídica.

Os novos dispositivos relativos à negociação coletiva não alteraram significativamente o papel dos sindicatos, mas trouxeram maior transparência e segurança para as negociações coletivas. 
ALMEIDA, Bruno Rotta; SALLET, Bruna Hoisler. Realidades prisionais e vulnerabilização étnica: aspectos sobre a questão indígena no sistema penitenciário brasileiro. Revista Eletrônica Direito e Política, Programa de Pós-Graduação Stricto Sensu em Ciência Jurídica da UNIVALI, Itajaí, v.13, n.3, 30 quadrimestre de 2018. Disponível em: www.univali.br/direitoepolitica - ISSN 1980-7791

Dentre as mudanças é importante a introdução do "princípio da intervenção mínima na autonomia da vontade coletiva", o que, convida as partes (empresas e sindicatos) a celebrarem acordos sem o temor de que eles serão sistematicamente atacados por instituições fiscalizadoras e anulados pela Justiça do Trabalho.

Um ambiente seguro e transparente propicia acordos coletivos robustos que contemplem cláusulas benéficas e relevantes para ambas as partes. Consequentemente, quando as partes celebram um acordo coletivo com cláusulas que atendam interesses de ambas as partes, existe uma maior probabilidade de renovação do acordo, tendo em vista que o impasse na renovação de um acordo bilateralmente benéfico não interessará a nenhum dos lados. Com a eliminação da ultratividade da norma coletiva fica reforçado o caminho da composição amigável de um novo acordo para se evitar que as cláusulas que interessam a empregados e patrões deixem de vigorar.

O fim da contribuição sindical obrigatória tornará economicamente inviável a atual fragmentação dos trabalhadores em milhares de pequenos sindicatos e fará com que ocorram fusões ou atuações em rede, um modelo mais representativo e melhor adaptado ao cenário mundial. Os sindicatos terão que se abrir à maior participação dos trabalhadores, que através da associação e contribuição associativa propiciarão o custeio das entidades sindicais.

Pelo exposto, os dispositivos relativos à negociação coletiva, em vigor desde 11 de novembro de 2017, podem resgatar o papel original de engajamento dos trabalhadores - de forma livre e consciente - para permitir um posicionamento fortalecido na interlocução com as empresas empregadoras.

Há duas maneiras de dar dinamismo à legislação trabalhista. A primeira é adotando uma legislação flexível, basicamente contratualista, como ocorre na América do Norte. A segunda é o envolvimento negocial de patrões e empregados, através de acordos ou convenções coletivas. Sem dúvida a segunda opção, sujeita a limites, é a que apresenta maior segurança jurídica para um país ainda em desenvolvimento econômico e com grandes diferenças sociais, inclusive em relação à maturidade do movimento sindical. 
ALMEIDA, Bruno Rotta; SALLET, Bruna Hoisler. Realidades prisionais e vulnerabilização étnica: aspectos sobre a questão indígena no sistema penitenciário brasileiro. Revista Eletrônica Direito e Política, Programa de Pós-Graduação Stricto Sensu em Ciência Jurídica da UNIVALI, Itajaí, v.13, n.3, 30 quadrimestre de 2018. Disponível em: www.univali.br/direitoepolitica - ISSN 1980-7791

Decerto que uma mudança tão contundente, tem o potencial de erros e acertos, cabendo aos operadores do direito, o papel de buscar explorá-la para a melhor aplicação - social e econômica - possível.

\section{REFERÊNCIA DAS FONTES CITADAS.}

BRASIL. Constituição da República Federativa do Brasil, Brasília, DF, 05 de outubro de $1988 . \quad$ Disponível em: https://www.planalto.gov.br/ccivil_03/Constituicao/ConstituicaoCompilado.htm. Acesso em: 02 set. 2017.

BRASIL. Câmara dos Deputados. Projeto de Lei 6787/2016. Disponível em http://www.camara.gov.br/proposicoesWeb/fichadetramitacao?idProposicao $=212$ 2076. Acesso em 11 de novembro de 2017;

BRASIL. Decreto-Lei 5.452 , de $1^{\circ}$ de maio de 1943. Aprova a Consolidação das Leis do Trabalho. Disponível em: http://www.planalto.gov.br/ccivil_03/decreto-lei/Del5452.htm. Acesso em 02 de set. 2017;

BRASIL. Lei no 13.467, de 13 de julho de 2017. Altera a Consolidação das Leis do Trabalho (CLT), aprovada pelo Decreto-Lei no 5.452, de 10 de maio de 1943, e as Leis nos 6.019, de 3 de janeiro de 1974, 8.036, de 11 de maio de 1990, e 8.212, de 24 de julho de 1991. Disponível em: http://www.planalto.gov.br/ccivil_03/_Ato2015-2018/2017/Lei/L13467.htm. Acesso em 02 set. 2017;

BRASIL. Resolução n. 17, de 1989 da Câmara dos Deputados. Aprova o Regimento Interno. Disponível em: http://bd.camara.gov.br/bd/handle/bdcamara/18847. Acesso em: 10. set. 2017.

BRASIL. Resolução n. 93, de 1970 do Senado Federal. Aprova o Regimento Interno. Disponível em: http://www25.senado.leg.br/web/atividade/regimentointerno. Acesso em: 10. set. 2017;

BRASIL. STF. Supremo Tribunal Federal. Recurso Extraordinário 590.415. Relator Ministro Roberto Barroso. Julgado em 30/04/2015;

BRASIL. STF. Supremo Tribunal Federal. Arguição de Descumprimento de Preceito Fundamental n. 323. Decisão cautelar proferida pelo Ministro Gilmar Mendes em 14/10/2016;

BRASIL. TST. Tribunal Superior do Trabalho. Recurso de Revista no TST-RR17000-58.2007.5.01.0343. Acórdão publicado em 16/09/2013; 
ALMEIDA, Bruno Rotta; SALLET, Bruna Hoisler. Realidades prisionais e vulnerabilização étnica: aspectos sobre a questão indígena no sistema penitenciário brasileiro. Revista Eletrônica Direito e Política, Programa de Pós-Graduação Stricto Sensu em Ciência Jurídica da UNIVALI, Itajaí, v.13, n.3, $3^{\circ}$ quadrimestre de 2018. Disponível em: www.univali.br/direitoepolitica - ISSN 1980-7791

CAMPOS, André Gambier. Sindicatos no Brasil: O que esperar no futuro próximo? Repositório do Conhecimento do IPEA, Rio de Janeiro, dez 2016, p. 9 e 12. Disponível em: http://repositorio.ipea.gov.br/handle/11058/7353. Acesso em 02 set. 2017;

CASSAR, Vólia Bomfim. CLT Comparada e Atualizada com a Reforma Trabalhista. São Paulo: Forense, 2018, 3a. ed., Nota da Editora.

HÄBERLE, Peter. Hermenêutica Constitucional. A Sociedade Aberta dos Intérpretes da Constituição: Contribuição para a interpretação pluralista e a "Procedimental" da Constituição. Porto Alegre: Sérgio Antônio Fabris Editor, 2002, p.17;

MAIOR, José Luiz Souto. "A CLT é velha". Disponível em: http://www.jorgesoutomaior.com/blog/i-a-clt-e-velha. Acesso em 01.09.2017;

MARTINS FILHO, Ives Gandra. Reflexões com Vistas à Modernização da Legislação Trabalhista por Ocasião dos 75 anos da Justiça do Trabalho no Brasil. $1^{0}$ Caderno de Pesquisas Trabalhistas. Porto Alegre: Lex Magister, 2017, p.12;

OLIVEIRA, Arolde de. Discurso proferido em audiência pública realizada em 23/03/2017 na Câmara dos Deputados. Brasília: 2017. Disponível em: http://www2.camara.leg.br/atividade-legislativa/comissoes/comissoestemporarias/especiais/55a-legislatura/pl-6787-16-reformatrabalhista/documentos/notas-taquigraficas/NT13ROAP230317.pdf. Acesso em 02 set. 2017;

RODRIGUES, Américo Plá. Princípios do Direito do Trabalho. São Paulo: Editora LTr, 1993, p.45;

SÜSSEKIND, Arnaldo. Direito Constitucional do Trabalho. Rio de Janeiro: Renovar, 2001, p.335;

SÜSSEKIND, Arnaldo. Curso de Direito do Trabalho. Rio de Janeiro: Renovar, 2002, p .529;

VIALARD, Antônio Vasquez. Derecho del Trabajo y Seguridad Social. Buenos Aires: Depalma, 1981, p. 178.

Recebido em: 29/11/2017

Aprovado em: 23/02/2018 